\title{
Selectivity of pre-and post-emergence herbicides to very-early maturing soybean cultivars
}

Felipe Guilherme Ferreira Fornazza'*, Jamil Constantin, Fellipe Goulart Machado', Rubem Silvério de Oliveira Jr. ', Gustavo Delabio da Silva', Fabiano Aparecido Rios'

'State University of Maringá, Maringá, Brazil

*Corresponding author, email: fellipe.goulart@outlook.com

\begin{abstract}
The combination of pre- and post-emergence herbicides may affect their selectivity to soybean plants, especially to short-cycle cultivars. The objective of this work was to evaluate the selectivity of pre- and post-emergence herbicides to very-early maturing soybean cultivars. Two field experiments were conducted, one in Mandaguaçu, Paraná (E1) and other in Rio Verde, Goiás (E2), Brazil, using a $4 \times 7$ factorial arrangement. The treatments consisted of four pre-emergence herbicide managements ( $\mathrm{S}$-metolachlor at $1440 \mathrm{~g} \mathrm{ha}^{-1}$, diclosulam at $25.2 \mathrm{~g} \mathrm{ha}^{-1}$, sulfentrazone at $300 \mathrm{~g} \mathrm{ha}^{-1}$, and no herbicide application); and seven post-emergence herbicide managements (lactofen at $120 \mathrm{~g} \mathrm{ha}^{-1}$, chlorimuron-ethyl at $12.5 \mathrm{~g} \mathrm{ha}^{-1}$, bentazon at $720 \mathrm{~g} \mathrm{ha}^{-1}$, lactofen at $120 \mathrm{~g}$

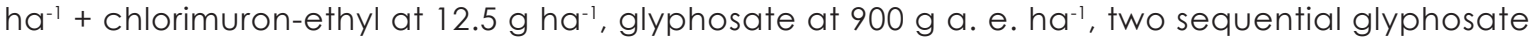
applications at $720 \mathrm{~g}$ a. e. ha-1 each, and no herbicide application). The early-maturing soybean cultivars evaluated showed sensitivity to the herbicides used. The combined use of pre- and post-emergence herbicides increased the occurrence of injuries in the plants. Diclosulam and sulfentrazone were the least selective pre-emergence herbicides. All herbicide combinations used affected soybean grain yield in El; lactofen, chlorimuron, and bentazon presented the least selectivity in E2.
\end{abstract}

Keywords: diclosulam, Glycine max, glyphosate, weed management

Introduction

The selection of resistant weeds to glyphosate in Brazil, especially Conyza spp. and Digitaria insularis (Heap, 2016), made the weed control more complex and farmers to use management systems with applications of pre- and post-emergence herbicides. Systems including combined applications of residual herbicides, such as sulfentrazone, diclosulam, and S-metolachlor, following applications of postemergence herbicides, such as glyphosate, have been used to manage weeds that are difficult to control-resistant or tolerant to herbicides (LopesOvejero et al., 2013).

The effect of herbicides can be

detrimental to soybean plants under certain conditions, causing injuries and decreasing their productivity (Santos et al., 2007; Alonso et al., 2010). The extent and intensity of these herbicideinduced injuries can vary depending on edaphoclimatic conditions, such as precipitation, soil carbon content, texture, and $\mathrm{pH}$, and level of susceptibility of soybean cultivars to herbicides (Taylor-Lovell et al., 2001; Belfry et al., 2015). The use of very-early maturing soybean cultivars with sequential applications of pre- and postemergence herbicides has raised concerns about their selectivity. Apparently, very-early maturing soybean cultivars are more susceptible to herbicides than cultivars with longer cycles 
(Zobiole et al., 2010).

Sulfentrazone, diclosulam, and S-metolachlor are pre-emergence herbicides frequently applied to soybean crops. They are described as selective for soybean crops, however, sulfentrazone can affect the growth and yield of some cultivars (Taylor-Lovell et al., 2001; Belfry et al., 2016), especially when combined with post-emergence herbicides. Diclosulam is selective when applied to medium to clayey soils (Gazola et al., 2016), but it may reduce the soybean grain yield when applied to soils with surface compaction (Biffe, 2012). S-metolachlor occasionally causes some initial phytotoxicity, but does not affect soybean growth and yield, presenting good selectivity to this crop (Mahoney et al., 2014; Belfry et al., 2015).

The main post-emergence herbicides available for soybean crops are inhibitors of PROTOX, ALS, and EPSPs. Post-emergence inhibitors of PROTOX and ALS can cause leaf injuries such as chlorosis and necrosis, affecting the plant development and productivity (Alonso et al., 2010). Glyphosate (EPSPs inhibitor) is the most commonly used herbicide in genetically modified soybean cultivars (Roundup Ready ${ }^{\circledR}$ ) and may have negative effects on nutrient uptake and plant growth (Bott et al., 2008; Zobiole et al., 2010).

The objective of this work was to evaluate the selectivity of pre- and post-emergence herbicides to very-early maturing soybean cultivars in weed management systems.

\section{Material and Methods}

Two field experiments were conducted in no-tillage system in the 2014/2015 crop season, using very-early maturing soybean cultivars recommended for the Southwest of Goiás (GO) and North of Paraná (PR), Brazil.

The first experiment (E1) was conducted in

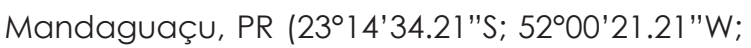
and $442 \mathrm{~m}$ of altitude) in soil with clayey texture. The soil analysis ( 0.00 to $0.20 \mathrm{~m}$ layer) presented $\mathrm{pH}$ in $\mathrm{CaCl}_{2}$ of $4.9,17 \mathrm{~g} \mathrm{dm}^{-3}$ of total carbon, $640 \mathrm{~g}$ $\mathrm{kg}^{-1}$ of clay, $141 \mathrm{~g} \mathrm{~kg}^{-1}$ of silt, $83 \mathrm{~g} \mathrm{~kg}^{-1}$ of fine sand, and $136 \mathrm{~g} \mathrm{~kg}^{-1}$ of coarse sand.

Experiment 2 (E2) was conducted in Rio Verde, GO (17\%45'49.11"S; 51 $01^{\circ}$ '54.52"W; and $840 \mathrm{~m}$ of altitude) in a soil with clay loam texture. The soil analysis (0.00 to $0.20 \mathrm{~m}$ layer) presented $\mathrm{pH}$ in $\mathrm{CaCl}_{2}$ of $5.1,19 \mathrm{~g} \mathrm{dm}^{-3}$ of total carbon, $328 \mathrm{~g}$ $\mathrm{kg}^{-1}$ of clay, $91 \mathrm{~g} \mathrm{~kg}^{-1}$ of silt, $124 \mathrm{~g} \mathrm{~kg}^{-1}$ of fine sand, and $457 \mathrm{~g} \mathrm{~kg}^{-1}$ of coarse sand.

Precipitation and temperature during the experiments are shown in Figure 1.

Manual weeding was performed when necessary during the soybean crop cycle to maintain all plots always free from weeds to avoid their interference on the results.

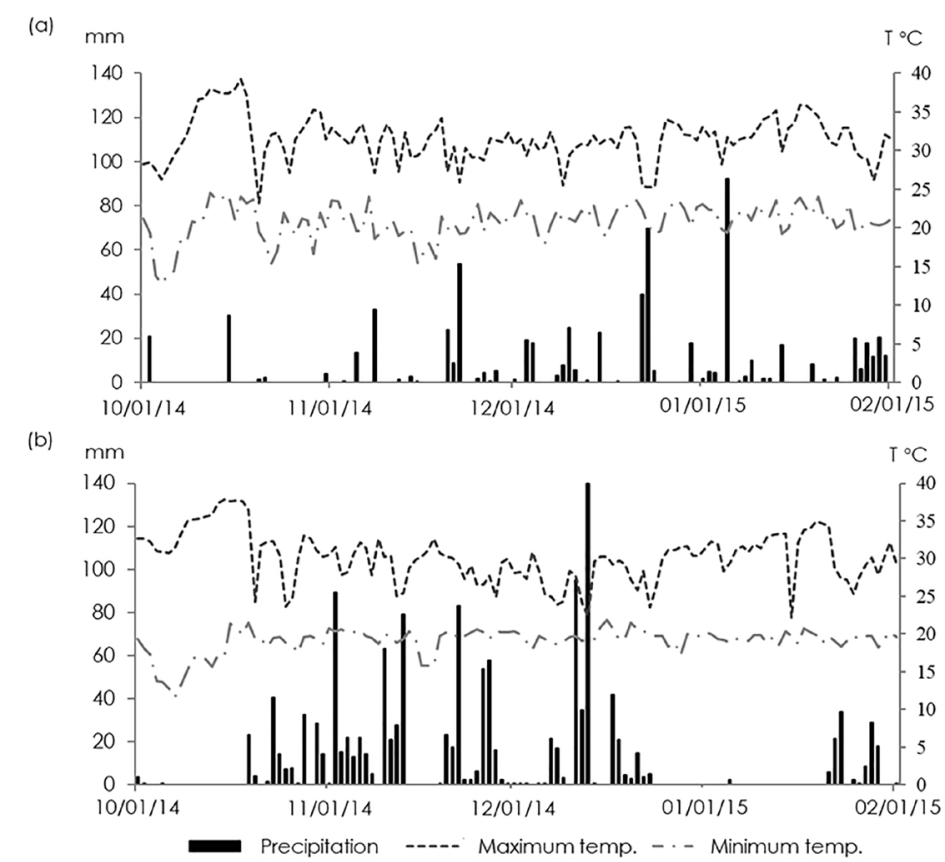

Figure 1. Precipitation and temperature data collected during the experiment period in Mandaguaçu, Paraná (a) and Rio Verde, Goiás (b), Brazil. 
The experiments were conducted in randomized block designs, using a $4 \times 7$ factorial arrangements, with 8 replications. The treatments consisted of four pre-emergence herbicide managements (S-metolachlor at $1440 \mathrm{~g} \mathrm{ha}^{-1}$, diclosulam at $25.2 \mathrm{~g} \mathrm{ha}^{-1}$, sulfentrazone at $300 \mathrm{~g}$ $\mathrm{ha}^{-1}$, and no herbicide application); and seven post-emergence herbicide managements (lactofen at $120 \mathrm{~g} \mathrm{ha}^{-1}$, chlorimuron-ethyl at 12.5 $\mathrm{g} \mathrm{ha}^{-1}$, bentazon at $720 \mathrm{~g} \mathrm{ha}^{-1}$, lactofen at $120 \mathrm{~g}$ $\mathrm{ha}^{-1}+$ chlorimuron-ethyl at $12.5 \mathrm{~g} \mathrm{ha}^{-1}$, glyphosate at $900 \mathrm{~g}$ a. e. $\mathrm{ha}^{-1}$, two sequential glyphosate applications at $720 \mathrm{~g}$ a. e. $\mathrm{ha}^{-1}$ each, and no herbicide application), totaling 28 treatments.

The experimental plots were $4.00 \mathrm{~m}$ long and $4.00 \mathrm{~m}$ wide $\left(16 \mathrm{~m}^{2}\right)$ and the central $9 \mathrm{~m}^{2}$ of the plots were considered for evaluation.

The soybean cultivars used were FPS
Iguaçu (E1) and NA 5909 RR (E2). These cultivars have indeterminate growth habit, beginning of reproductive phase at 30 to 45 days, and an expected cycle of 100 to 105 days (Fundação Pró Sementes, 2016; Sementes Goiás, 2016).

Applications of $400 \mathrm{~g} \mathrm{ha}^{-1}$ of paraquat were performed before the implementation of the experiments to kill the emerged weeds. Information about the soybean cultivars and cultural practices used are shown on Table 1. Pest and disease controls were performed when necessary to avoid interference of them on the results.

The herbicides were applied using a $\mathrm{CO}_{2}$. pressurized sprayer with five single fan jet nozzles (XR-1 10.02) spaced $0.5 \mathrm{~m}$ apart, solution volume of $180 \mathrm{~L} \mathrm{ha}^{-1}$, and spray pressure of $2.0 \mathrm{kgf}^{-2}$ (Table 2).

Table 1. Dates of seeding, emergence, and harvest of soybean plants, and cultural practices used.

\begin{tabular}{lcc}
\hline & Experiment 1 & Experiment 2 \\
\hline Location & MandaguaçU, PR & Rio Verde, GO \\
Cultivar & FPS IGUAÇU RR & NA 5909 RR \\
Seeding date & $11 / 07 / 2014$ & $10 / 30 / 2014$ \\
Emergence date & $11 / 12 / 2014$ & $11 / 04 / 2014$ \\
Harvest date & $01 / 31 / 2015$ & $01 / 21 / 2015$ \\
Space between rows (cm) & 0.45 & 0.5 \\
Seed density ha-1 & 400000 & 360000 \\
N-P-K fertilizing $\left(\mathrm{kg} \mathrm{ha}^{-1}\right)$ & $0-60-60$ & $6-60-54$ \\
\hline
\end{tabular}

Table 2. Application of pre-emergence and post-emergence herbicides for soybean plants.

\begin{tabular}{lcccccc}
\hline & \multicolumn{3}{c}{ MandaguaçU, PR (E1) } & \multicolumn{3}{c}{ Rio Verde, GO (E2) } \\
\cline { 2 - 7 } & Pre & Post & Seq & Pre & Post & Seq \\
\cline { 2 - 6 } Application day & $11 / 10 / 14$ & $12 / 03 / 14$ & $12 / 18 / 14$ & $10 / 31 / 14$ & $11 / 29 / 14$ & $12 / 12 / 14$ \\
Days after seeding & 0 & 23 & 38 & 0 & 29 & 42 \\
Air relative humidity & 68 & 85 & 72 & 72 & 55 & 88 \\
Air temperature $\left({ }^{\circ} \mathrm{C}\right)$ & 23 & 22 & 30.4 & 29 & 31 & 28.5 \\
Wind speed $\left(\mathrm{km} \mathrm{h}^{-1}\right)$ & 0.2 & 2 & 1.3 & 0.5 & 1.5 & 3.5 \\
Soil moisture & wet & wet & wet & wet & wet & wet \\
Hours/depth $\left(\mathrm{h} / \mathrm{mm}^{*}{ }^{*}\right.$ & $42 / 1$ & $24 / 5$ & $72 / 40$ & $04 / 5$ & $06 / 32$ & $06 / 140$ \\
Days after seeding & 3 & 24 & 38 & 1 & 28 & 41 \\
\hline Pre = application of pre-emergence herbicide; Post = application of post-emergence herbicide; Seq = sequential application of post-emergence herbicides; ${ }^{*=\text { hour of }}$ \\
the first precipitation event after the herbicide application, and precipitation depth.
\end{tabular}

Soybean leaf injuries caused by the herbicides used were evaluated visually, based on a $0 \%$ to $100 \%$ scale, wherein $0 \%$ is equivalent to no damage, and $100 \%$ is equivalent to the death of all plants (SBCPD, 1995). Plants in El were evaluated at 15 days after the pre-emergence application $\left(D_{A A} A_{P R}\right)$ and at 7, 22, and 37 days after the post-emergence applications (DAA ${ }_{\text {POST }}$ ). Plants in E2 were evaluated at $15 \mathrm{DAA}_{\mathrm{PRE}}$ and at 1 , 16, and 31 DAA $_{\text {POST }}$.
Plant height was evaluated before the soybean harvest using five random plants of the evaluation area of the plots. The plants in the central three meters of the four central rows of each plot $\left(6 \mathrm{~m}^{2}\right)$ were manually harvested and threshed. Grain moisture was determined using an electric moisture meter and corrected to $14 \%$ moisture to evaluate grain yield $\left(\mathrm{kg} \mathrm{ha}^{-1}\right)$.

The data were analyzed using the Shapiro Wilk normality test. The $4 \times 7$ factorial arrangement 
was subjected to analysis of variance, in which the pre-emergence herbicides were factor 1 and the post-emergence herbicides were the factor 2. Significant results were subjected to the ScottKnott test ( $p \leq 0.05)$.

\section{Results and Discussion}

Toxicity of herbicides to soybean plants

Plants in Experiment 1 (E1) treated with pre-emergence application of diclosulam (25.2 $\mathrm{g} \mathrm{ha}^{-1}$ ) presented higher injuries $(5.1 \%)$ at 15 $D A_{\text {PRE }}$ than those treated with the other preemergence herbicides. Plants in Experiment 2 (E2) presented similar results, with $7 \%$ of injuries, and shrinkage of younger trifoliate leaves (data not presented). Symptoms were similar in both experiments, regardless of the variations in soil and precipitation, and soybean cultivars.

Plants in El treated with sulfentrazone (300 $\mathrm{g} \mathrm{ha}^{-1}$ ) had $3.4 \%$ of injuries, reduced size, and leaf chlorosis. Plants in E2 treated with sulfentrazone had $29 \%$ of injuries (data not shown). Sulfentrazone is an inhibitor of the protoporphyrinogen oxidase enzyme (PROTOX) and has low mobility in the soil; it concentrates mainly in the soil surface layer and, when there is a contact between plants and treated soil surface, they may present tanning and necrosis, and delayed development, even in species that are tolerant to herbicides (Oliveira Jr., 2011). Soils with high moisture and $\mathrm{pH}$ and low clay content generate more intense toxic effects of sulfentrazone on plants since the availability of this herbicide in the soil solution is concentrated on the soil surface (Blanco et al., 2010). The highest percentage of injuries of plants in E2 caused by sulfentrazone was probably due to the lower soil clay content (324 $\left.\mathrm{g} \mathrm{kg}^{-1}\right)$ of this experimental area, and the occurrence of precipitation on the day of application (28 $\mathrm{mm})$, and on the following five days after the pre-emergence herbicide application (141 mm). Contrastingly, the soil of the $\mathrm{El}$ is clayey $(640 \mathrm{~g}$ $\mathrm{kg}^{-1}$ of clay), and no precipitations occurred until ten days after application of the preemergence herbicides, thus, reducing herbicide activity and concentration in the soil solution. Osipe et al. (2014) evaluated the selectivity of diclosulam and sulfentrazone to soybean using the same rates used in the present study and observed leaf injuries and reduction in the stand of plants. S-metolachlor (1440 $\mathrm{g} \mathrm{ha}^{-1}$ ) was the most selective herbicide in E1 and E2 in the same evaluation (15 DAA $A_{\text {PRE }}$ ) (data not shown). Similar results for S-metolachlor selectivity was found in other studies, with no injuries in soybean plants, even when using higher rates (up to 3,200 $\mathrm{g} \mathrm{ha}^{-1}$ ) in pre-emergence applications (Mahoney et al., 2014; Belfry et al., 2015).

Regarding the post-emergence herbicides, no injuries were found in plants in E2 at 1, 16, and $31 \mathrm{DAA}_{\text {post }}$. The interaction between pre-emergence and post-emergence herbicides was significant for plants in El (Table 3).

Table 3. Percentage of injuries in soybean plants (FPS IguaçU RR cultivar) caused by pre-emergence and postemergence herbicides, at 7 days after the post-emergence applications. Mandaguaçu, Paraná, Brazil, 2014/2015 crop season.

\begin{tabular}{|c|c|c|c|c|}
\hline \multirow{2}{*}{ Post-emergence herbicide } & \multicolumn{4}{|c|}{ Pre-emergence herbicide } \\
\hline & S-metolachlor & Diclosulam & Sulfentrazone & $\mathrm{NHA}$ \\
\hline Lactofen & $6.9 \mathrm{Bb}$ & $14.4 \mathrm{Ab}$ & $8.1 \mathrm{Bb}$ & $6.3 \mathrm{Bb}$ \\
\hline Chlorimuron ${ }^{1}$ & $2.5 \mathrm{BC}$ & $10.6 \mathrm{Ac}$ & $4.0 \mathrm{BC}$ & $2.5 \mathrm{BC}$ \\
\hline Bentazon ${ }^{1}$ & $0.0 \mathrm{AC}$ & $0.6 \mathrm{Ad}$ & $0.0 \mathrm{Ad}$ & $0.0 \mathrm{Ac}$ \\
\hline 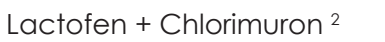 & $20.0 \mathrm{Ba}$ & $23.8 \mathrm{Aa}$ & $21.3 \mathrm{Ba}$ & $18.8 \mathrm{Ba}$ \\
\hline Glyphosate & $0.0 \mathrm{Ac}$ & $0.6 \mathrm{Ad}$ & $1.3 \mathrm{Ad}$ & $0.0 \mathrm{AC}$ \\
\hline Glyphosate - Glyphosate ${ }^{3}$ & $8.1 \mathrm{Ab}$ & $9.4 \mathrm{AC}$ & $8.8 \mathrm{Ab}$ & $6.9 \mathrm{Ab}$ \\
\hline NHA & $0.0 \mathrm{AC}$ & $0.0 \mathrm{Ad}$ & $0.0 \mathrm{Ad}$ & $0.0 \mathrm{Ac}$ \\
\hline CV (\%) & 30.28 & & & \\
\hline
\end{tabular}

Means followed by the same uppercase letter in the rows or lowercase letter in the columns do not differ by the Scott-Knott test ( $p \leq 0.05)$. S-metolachlor (1440 $\mathrm{g}$ ha-1): diclosulam (25.2 $\left.\mathrm{g} \mathrm{ha}^{-1}\right)$; sulfentrazone (300 $\left.\mathrm{g} \mathrm{ha}^{-1}\right)$; lactofen (120 $\left.\mathrm{g} \mathrm{ha}^{-1}\right)$; chlorimuron-ethyl (12.5 $\left.\mathrm{g} \mathrm{ha}^{-1}\right)$; bentazon (720 $\left.\mathrm{g} \mathrm{ha}^{-1}\right)$; lactofen (120 $\left.\mathrm{g} \mathrm{ha}^{-1}\right)+$ chlorimuron-ethyl (12.5 $\mathrm{g} \mathrm{ha}^{-1}$ ): glyphosate (900 $\mathrm{g}$ a. e. $\mathrm{ha}^{-1}$ ); NHA = No herbicide application; ' $=$ addition of mineral oil (Assist $\left.0.5 \% \mathrm{v} / \mathrm{v}\right){ }^{2}$ applied together in a mixed solution; ${ }^{3}$ two sequential applications of glyphosate (720 g a. e. ha $^{-1}$ each); $\mathrm{CV}=$ coefficient of variation.

Regarding the post-emergence herbicides, Lactofen (120 $\left.\mathrm{g} \mathrm{ha}^{-1}\right)+$ chlorimuron ( $\left.12.5 \mathrm{~g} \mathrm{ha}^{-1}\right)$, and lactofen ( $\left.120 \mathrm{~g} \mathrm{ha}^{-1}\right)$ caused the greatest injuries to soybean plants at 7 DAA POST $_{\text {in all }}$ combinations with the pre-emergence herbicides (S-metolachlor, diclosulam, sulfentrazone), and with no application of pre-emergence herbicide. However, the greatest injuries were found in 
plants treated with diclosulam (Table 3). The high percentage of injuries caused by lactofen may be due to its mechanism of action (inhibitor of PROTOX), which causes lipid peroxidation and, consequently, loss of chlorophyll and rupture of membranes, generating necrosis and chlorotic points in leaves (Oliveira Jr., 2011). Effects of lactofen on soybean plants are usually more expressive soon after its application, with occurrence of high percentages of injuries at 7 days after application, and reduced toxicity from the emission of new leaves (Galon et al., 2007), as observed at 22 and $37 \mathrm{DAA}_{\text {post }}$ (data not shown).

The treatment with two sequential application of glyphosate caused mild chlorosis to the leaves. When glyphosate is applied to genetically modified soybean plants (Roundup Ready $^{\circledR}$ ), it may cause immobilization of bivalent and trivalent cations, decreasing the Fe and $\mathrm{Mn}$ contents in leaf tissues, generating chlorosis (Zobiole et al., 2010). Despite the injuries caused to the plants, a single application of glyphosate or bentazon presented higher selectivity compared to the other post-emergence herbicides, not differing from the treatment with no herbicide application.

\section{Plant height}

The interaction between the factors (preand post-emergence herbicides) was significant (Table 4) for plant height at preharvest. The combination of S-metolachlor with chlorimuron resulted in higher plant heights than the other combinations of pre-emergence herbicides with post-emergence application of chlorimuron.

The combination of diclosulam with

Table 4. Soybean plant heights before harvest as a function of applications of pre-emergence and post-emergence herbicides. Mandaguaçu, Paraná (E1) and Rio Verde, Goiás (E2), Brazil, 2014/2015 crop season.

\begin{tabular}{|c|c|c|c|c|}
\hline \multirow{3}{*}{ Post-emergence herbicide } & \multicolumn{4}{|c|}{ El (FPS Iguaçu RR) } \\
\hline & \multicolumn{4}{|c|}{ Pre-emergence herbicide } \\
\hline & S-metolachlor & Diclosulam & Sulfentrazone & $\mathrm{NHA}$ \\
\hline Lactofen & $98 \mathrm{Aa}$ & $97 \mathrm{Aa}$ & $96 \mathrm{Aa}$ & $84 \mathrm{Bb}$ \\
\hline Chlorimuron' & $98 \mathrm{Aa}$ & $90 \mathrm{Ba}$ & $88 \mathrm{Ba}$ & $91 \mathrm{Ba}$ \\
\hline Bentazon' & $99 \mathrm{Aa}$ & $85 \mathrm{Bb}$ & $92 \mathrm{Aa}$ & $93 \mathrm{Aa}$ \\
\hline Lactofen + Chlorimuron ${ }^{2}$ & $92 \mathrm{Ab}$ & $92 \mathrm{Aa}$ & $91 \mathrm{Aa}$ & $84 \mathrm{Ab}$ \\
\hline Glyphosate & $92 \mathrm{Ab}$ & $92 \mathrm{Aa}$ & $78 \mathrm{Bb}$ & $96 \mathrm{Aa}$ \\
\hline Glyphosate - Glyphosate ${ }^{3}$ & $95 \mathrm{Aa}$ & $77 \mathrm{BC}$ & $91 \mathrm{Aa}$ & $95 \mathrm{Aa}$ \\
\hline $\mathrm{NHA}$ & $85 \mathrm{Bb}$ & $93 \mathrm{Aa}$ & $95 \mathrm{Aa}$ & $97 \mathrm{Aa}$ \\
\hline CV (\%) & 7.63 & & & \\
\hline \multirow{3}{*}{ Post-emergence herbicide } & \multicolumn{4}{|c|}{ E2 (NA 5909 RR) } \\
\hline & \multicolumn{4}{|c|}{ Pre-emergence herbicide } \\
\hline & S-metolachlor & Diclosulam & Sulfentrazone & $\mathrm{NHA}$ \\
\hline Lactofen & $52 \mathrm{Aa}$ & $46 \mathrm{Ba}$ & $45 \mathrm{Ba}$ & $52 \mathrm{Aa}$ \\
\hline Chlorimuron' & $50 \mathrm{Ba}$ & $46 \mathrm{Ca}$ & $45 \mathrm{Ca}$ & $55 \mathrm{Aa}$ \\
\hline Bentazon' & $51 \mathrm{Ba}$ & $51 \mathrm{Ba}$ & $48 \mathrm{Ba}$ & $55 \mathrm{Aa}$ \\
\hline Lactofen + Chlorimuron ${ }^{2}$ & $49 \mathrm{Aa}$ & $49 \mathrm{Aa}$ & $44 \mathrm{Ba}$ & $50 \mathrm{Aa}$ \\
\hline Glyphosate & $52 \mathrm{Ba}$ & $49 \mathrm{Ba}$ & $44 \mathrm{Ca}$ & $55 \mathrm{Aa}$ \\
\hline Glyphosate - Glyphosate ${ }^{3}$ & $51 \mathrm{Aa}$ & $52 \mathrm{Aa}$ & $48 \mathrm{Aa}$ & $55 \mathrm{Aa}$ \\
\hline $\mathrm{NHA}$ & $55 \mathrm{Aa}$ & $48 \mathrm{Ba}$ & $48 \mathrm{Ba}$ & $55 \mathrm{Aa}$ \\
\hline
\end{tabular}

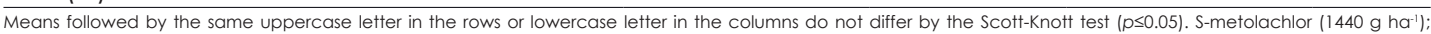

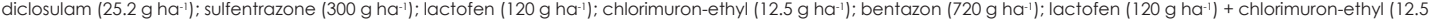
$\mathrm{g} \mathrm{ha}^{-1}$ ); glyphosate (900 g a. e. ha-1); NHA = No herbicide application; ' $=$ addition of mineral oil (Assist $0.5 \% \mathrm{v} / \mathrm{v}$ ); ${ }^{2}$ applied together in a mixed solution; ${ }^{3}$ two sequential applications of glyphosate (720 g a. e. ha $^{-1}$ each); CV = coefficient of variation.

bentazon or with two sequential glyphosate applications in El resulted in lower plant heights than the other combinations of diclosulam with post-emergence herbicides. The application of sulfentrazone combined with glyphosate resulted in plants with heights $18 \mathrm{~cm}$ lower than those in the treatment with no pre-emergence herbicide application. Osipe et al. (2014) evaluated the selectivity of this herbicide to soybean plants (V-MAX RR cultivar) and found that preemergence application of diclosulam followed by post-emergence application of glyphosate affected the plant height; this effect was not observed for sulfentrazone, with no differences between the treatment with sulfentrazone and post-emergence application of glyphosate and 
the treatment with no herbicide application, which differs from the results found in the present study.

The pre-emergence application of diclosulam or sulfentrazone with two sequential post-emergence applications of glyphosate or with single application of glyphosate resulted in lower plant heights when compared to the treatment with no post-emergence herbicide application. Similar results were found in other studies, with glyphosate affecting the soybean plant height (Zobiole et al., 2010; Casonatto et al., 2014; Osipe et al., 2014). However, when no pre-emergence herbicide was applied or a pre-emergence application of S-metolachlor was applied, the post-emergence application of glyphosate and the treatment with no postemergence herbicide application had similar results. Similarly, Mendonça Filho et al. (2010) and Basso et al. (2011) evaluated post-emergence application of glyphosate rates up to $1440 \mathrm{~g}$ a. e. $\mathrm{ha}^{-1}$ in soybean crops and found no effects of this herbicide on plant height and grain yield.

Plants in El with no pre-emergence herbicide application and with single or combined application of lactofen and chlorimuron presented lower heights than plants treated with post-emergence herbicides. These herbicides caused the highest percentages of injuries in the plants and, consequently, affected the final height of plants at preharvest.

No differences in plant height between the post-emergence herbicides applied were found in E2. The plant height varied between 44 and $55 \mathrm{~cm}$, which are smaller than the average heights (65 to $85 \mathrm{~cm}$ ) described for the NA 5909 RR soybean cultivar (Sementes Goiás, 2016). The water stress occurred during the reproductive period of the soybean (R3 to R5) in E2 (Rio Verde, GO) probably affected the crop development, since water stress in this critical period may affect the plant's growth, reproductive capacity, and cycle (Farias et al., 2007). Despite this water stress, some combinations of pre- and postemergence herbicides resulted in less selectivity. Pre-emergence applications of diclosulam, and sulfentrazone, and post-emergence application of lactofen, and chlorimuron resulted in lowerplant heights than the pre-emergence applications with S-metolachlor, and with no pre-emergence herbicide application (Table 4). This result denotes the higher selectivity of S-metolachlor. However, plants in treatments with pre-emergence application of S-metolachlor, diclosulam, and sulfentrazone, and post-emergence application of chlorimuron, bentazon, and glyphosate had lower heights than those of the treatment with no pre-emergence herbicide application. The treatment with post-emergence application of glyphosate (900 $\mathrm{g} \mathrm{ha}^{-1}$ ) combined with preemergence application of sulfentrazone resulted in the lowest plant heights, followed by the treatments with S-metolachlor, and diclosulam, all presenting lower plant heights than the treatment with no pre-emergence herbicide application. Therefore, the combination of preand post-emergence herbicides affect the soybean plant height.

\section{Grain yield}

The climatic conditions in El (Mandaguaçu, PR) favored the development of soybean plants, with precipitation of approximately $606 \mathrm{~mm}$ during the crop cycle, with well distributed rainfalls and no drought periods longer than five days (Figure 1); whereas the E2 (Rio Verde, GO) had no favorable precipitations during the crop cycle, causing water stress during the reproductive period of the soybean plants, reducing the crop cycle in 15 days (Table 2), since the NA 5909 RR cultivar has crop cycles ranging from 100 to 105 days (Sementes Goiás, 2016).

The interaction between pre- and post-emergence herbicides was significant for soybean grain yield in both experiments (Table 5). All combinations of herbicides in El resulted in lower grain yield than the treatment with no herbicide application, denoting the negative effects of these combinations on very-early maturing soybean cultivars.

According to Mahoney et al., 2014), the S-metolachlor and sulfentrazone herbicides cause injuries to plants of long-maturing soybean cultivars ( 118 to 151 days), but with no decrease in grain yield. Apparently, the tolerance of soybean cultivars to sulfentrazone herbicide varies. More tolerant cultivars show no injuries 
due to the rapid metabolization of this herbicide,

at the reaction center of the protoporphyrinogen which is stimulated by the oxidative stress caused oxidase enzyme (Taylor-Lovell et al., 2001).

Table 5. Soybean grain yield as a function of application of pre-emergence and post-emergence herbicides. Mandaguaçu, Paraná (E1) and Rio Verde, Goiás (E2), Brazil, 2014/2015 crop season.

\begin{tabular}{|c|c|c|c|c|}
\hline \multirow{3}{*}{ Post-emergence herbicide } & \multicolumn{4}{|c|}{ Pre-emergence herbicide } \\
\hline & \multicolumn{4}{|c|}{ El (FPS Iguaçu RR soybean cultivar) } \\
\hline & S-metolachlor & Diclosulam & Sulfentrazone & NHA \\
\hline Lactofen & $3093.0 \mathrm{Bb}$ & $2905.2 \mathrm{BC}$ & $2859.6 \mathrm{BC}$ & $3558.0 \mathrm{AC}$ \\
\hline Chlorimuron' & $2986.8 \mathrm{BC}$ & $2686.2 \mathrm{Bd}$ & $2781.0 \mathrm{BC}$ & $3466.2 \mathrm{AC}$ \\
\hline Bentazon' & $3184.8 \mathrm{Bb}$ & $3129.6 \mathrm{Bb}$ & $2946.0 \mathrm{BC}$ & $3670.2 \mathrm{AC}$ \\
\hline Lactofen + Chlorimuron ${ }^{2}$ & $2814.0 \mathrm{BC}$ & $2643.0 \mathrm{Bd}$ & $2667.0 \mathrm{BC}$ & $3108.0 \mathrm{Ad}$ \\
\hline Glyphosate & $3326.4 \mathrm{Bb}$ & $3197.4 \mathrm{Bb}$ & $3172.2 \mathrm{Bb}$ & $3795.0 \mathrm{Ab}$ \\
\hline Glyphosate - Glyphosate ${ }^{3}$ & $3153.0 \mathrm{Bb}$ & $3006.0 \mathrm{BC}$ & $3282.0 \mathrm{Bb}$ & $3571.2 \mathrm{AC}$ \\
\hline $\mathrm{NHA}$ & $3773.4 \mathrm{Ba}$ & $3489.6 \mathrm{Ba}$ & $3575.4 \mathrm{Ba}$ & $4150.2 \mathrm{Aa}$ \\
\hline CV (\%) & 8.32 & & & \\
\hline \multirow{3}{*}{ Post-emergence herbicide } & \multicolumn{4}{|c|}{ E2 (NA 5909 RR soybean cultivar) } \\
\hline & \multicolumn{4}{|c|}{ Pre-emergence herbicide } \\
\hline & S-metolachlor & Diclosulam & Sulfentrazone & $\mathrm{NHA}$ \\
\hline Lactofen & $3196.2 \mathrm{Aa}$ & $2790.0 \mathrm{Ba}$ & $2569.8 \mathrm{Ba}$ & $3397.8 \mathrm{Aa}$ \\
\hline Chlorimuron' & $3019.2 \mathrm{Aa}$ & $2408.4 \mathrm{Ba}$ & $2442.0 \mathrm{Ba}$ & $3488.4 \mathrm{Aa}$ \\
\hline Bentazon' & $2623.2 \mathrm{Ba}$ & $2766.6 \mathrm{Ba}$ & $2729.4 \mathrm{Ba}$ & $3358.2 \mathrm{Aa}$ \\
\hline Lactofen + Chlorimuron ${ }^{2}$ & $3112.2 \mathrm{Aa}$ & $2830.8 \mathrm{Aa}$ & $2464.8 \mathrm{Aa}$ & $3045.6 \mathrm{Aa}$ \\
\hline Glyphosate & $3203.4 \mathrm{Aa}$ & $2965.8 \mathrm{Aa}$ & $2746.8 \mathrm{Aa}$ & $3522.6 \mathrm{Aa}$ \\
\hline Glyphosate - Glyphosate ${ }^{3}$ & $2883.0 \mathrm{Aa}$ & $2676.0 \mathrm{Aa}$ & $2334.6 \mathrm{Aa}$ & $3111.6 \mathrm{Aa}$ \\
\hline $\mathrm{NHA}$ & $3436.2 \mathrm{Aa}$ & $3089.4 \mathrm{Aa}$ & $2994.6 \mathrm{Aa}$ & $3655.8 \mathrm{Aa}$ \\
\hline CV (\%) & 19.75 & & & \\
\hline
\end{tabular}

All applications of pre-emergence herbicides in El combined with post-emergence applications of lactofen + chlorimuron or chlorimuron caused great grain yield loss. The use of these post-emergence herbicides combined with pre-emergence treatments (S-metolachlor, diclosulam, sulfentrazone, and no herbicide application) presented grain yield losses of $25 \%$ (lactofen + chlorimuron) and $21 \%$ (chlorimuron), compared to the treatment with no post-emergence herbicide application. The post-emergence applications of lactofen (144 g $\mathrm{ha}^{-1}$ ) or lactofen (96 $\mathrm{g} \mathrm{ha}^{-1}$ ) + chlorimuron (17,5 $\mathrm{g} \mathrm{ha}^{-1}$ ) cause leaf injuries and reduce the plant development, and post-emergence application of chlorimuron or lactofen with glyphosate cause leaf injuries of $50 \%$ and $65 \%$, respectively, with decreases in plant height, and grain yield; however, the toxic effects of these herbicides are reduced when they are applied alone (Alonso et al., 2010). These results agree with those found in the present study, in which the application of lactofen + chlorimuron resulted in low herbicide selectivity, affecting the evaluated characteristics, including grain yield.

The pre-emergence application of S-metolachlor combined with any of the postemergence herbicides resulted in lower grain yield than the treatment with pre-emergence application of S-metolachlor with no postemergence herbicide application. However, applications of lactofen + chlorimuron or chlorimuron were the least selective, presenting plants with grain yields $15.5 \%$ lower than those with pre-emergence application of S-metolachlor with no post-emergence herbicide.

All combinations of post-emergence herbicides applied after pre-emergence application of diclosulam or sulfentrazone resulted in grain yield loss when compared to the treatments with only pre-emergence application (diclosulam with no post-emergence herbicide, and sulfentrazone with no post-emergence herbicide). The combination of pre-emergence application of diclosulam with post-emergence application of bentazon (720 $\mathrm{g} \mathrm{ha}^{-1}$ ) or glyphosate (900 $\mathrm{g} \mathrm{a.} \mathrm{e.} \mathrm{ha}^{-1}$ ) resulted in the lowest grain yield losses, $10 \%$ and $8 \%$, respectively. The combinations 
of pre-emergence application of sulfentrazone with post-emergence application of glyphosate (one, or two sequential applications) were the most selective, but they decreased grain yields by $8 \%$, and $11 \%$, respectively.

Plants treated with no pre-emergence herbicides, with post-emergence application of glyphosate (one, or two sequential applications) presented grain yield losses of $8.6 \%$, and $14.0 \%$, respectively. The application of pre-emergence herbicides (S-metolachlor, diclosulam, and sulfentrazone) combined with glyphosate (one, or two sequential applications) resulted in grain yield losses $15 \%$ and $12 \%$, respectively, compared to the treatment with no pre-emergence herbicide application. Despite the adverse effects on soybean plants, glyphosate is still the most used herbicide for weed management for soybean crops because it presents a broad spectrum of control when compared to the other post emergence herbicides applied. The effects of glyphosate on genetically modified soybean plants (Roundup Ready ${ }^{\circledR}$ ) may vary according to the cultivar, maturating group, application time, and rate used (Oliveira Jr. et al., 2008). The evaluated soybean cultivars (FPS Iguaçu RR, and NA 5909 RR) present similar cycle and growth habit, but presented differences in herbicide selectivity. These differences may be related to the tolerance of each cultivar to the herbicides used and to the different edaphoclimatic factors of the evaluated areas.

Santos et al. (2007), Bott et al. (2008), Zobiole et al. (2010) and Casonatto et al. (2014) reported the toxic effects of glyphosate on genetically modified soybean plants (Roundup Ready $\left.^{\circledR}\right)$. Plants treated with glyphosate may present leaf chloroses, smaller amounts of root nodules, lower plant heights, and lower nutrient contents. The prevention of the negative effects of glyphosate on RR soybean cultivars has been considered in recent studies, with the use of products that minimize leaf injuries and preserve the plant productive potential (Constantin et al., 2016).

The post-emergence applications of lactofen or chlorimuron combined with preemergence applications of diclosulam, and sulfentrazone in E2 resulted in less selectivity when compared to these herbicides combined with pre-emergence application of S-metolachlor or with no pre-emergence application.

The combination of post-emergence application of lactofen with pre-emergence application of diclosulam, or sulfentrazone decreased grain yield by $18 \%$, and $24 \%$, respectively, when compared to the combination of lactofen with no pre-emergence herbicide, and by $12.7 \%$ and $19.6 \%$ when this treatment was combined with pre-emergence application of S-metolachlor. The combination of post-emergence application of chlorimuron with pre-emergence application of diclosulam, or sulfentrazone resulted in even higher grain yield losses, $30 \%$ lower than that of the combination of chlorimuron with no pre-emergence herbicide.

The pre-emergence herbicides

(S-metolachlor, diclosulam, and sulfentrazone) combined with post-emergence application of bentazon, reduced the grain yield in $22 \%$, $18 \%$, and $19 \%$, respectively, when compared to the treatment with no pre-emergence herbicides. The combination of bentazon with the preemergence herbicides increased plant injuries. The selectivity of post-emergence application of bentazon + glyphosate is low, presenting leaf injuries and reduced grain yield (Alonso et al., 2010). However, soybean plants have tolerance to bentazon due to metabolization and detoxification processes, reducing the toxic effects of this product (Zhu et al., 2009). The selectivity of bentazon in E1 and E2 was limited, especially when pre-emergence herbicides were used, denoting that the toxicity effects of preand post-emergence herbicides can reduce soybean grain yield.

\section{Conclusions}

The very-early maturing soybean cultivars FPS IguaçU, and NA 5909 RR presented sensitivity to the herbicides used.

The diclosulam and sulfentrazone herbicides caused higher percentage of injuries in soybean plants in both experiments than the other pre-emergence herbicides applied; and S-metolachlor presented the highest selectivity.

All pre- and post-emergence herbicides applied to plants in Experiment 1 showed limited 
selectivity to the soybean crops, and decreased grain yield when compared to the treatments with no herbicide application. The post-emergence application of chlorimuron + lactofen was the least selective, and glyphosate $(900 \mathrm{~g}$ a. e. ha 1) was the most selective herbicide to soybean plants.

Combinations of the post-emergence herbicides lactofen, chlorimuron, or bentazon with pre-emergence herbicides in Experiment 2 resulted in low selectivity, and reduced grain yield. The other treatments were selective under the conditions of this experiment.

\section{References}

Alonso, D.G., Constantin, J., Oliveira Jr., R.S., Biffe, D.F., Raimondi, M.A., Gemelli, A., Carneiro, J.C. 2010. Selectivity of glyphosate in tank mixtures for RR soybean in sequential applications with mixtures only in the first or second application. Planta Daninha 28: 865-875.

Basso, C.J., Santi, A.L., Lamego, F.P., Girotto, E. 2011. Aplicação foliar de manganês em soja transgênica tolerante ao glyphosate. Ciência Rural 41: 1726-1731.

Belfry, K.D., Shropshire, C., Sikkema, P.H. 2015. Tolerance of identity preserved soybean variedades to pre-emergence herbicides. Canadian Journal of Plant Science 95: 719-726.

Belfry, K.D., Shropshire, C., Sikkema, P.H. 2016. Identity-preserved soybean tolerance to protoporphyrinogen oxidase-inhibiting herbicides. Weed Technology 30: 137-147.

Biffe, D.F. 2012. Efeito da aplicação de herbicidas em pré-emergência e de glyphosate em pósemergência sobre a cultura da soja $R R$, em solo compactado e não compactado. 104f. (Tese de Doutorado) - Universidade Estadual de Maringá, Maringá, Brasil.

Blanco, F.M.G., Velini, E.D., Batista Filho, A. 2010. Persistência do herbicida sulfentrazone em solo cultivado com cana-de-açúcar. Bragantia 69: 71-75.

Bott, S., Tesfamariam, T., Candan, H., Cakmak, I., Römheld, V., Neumann, G. 2008. Glyphosateinduced impairment of plant growth and micronutrient status in glyphosate-resistant soybean (Glycine max L.). Plant and Soil 312: 185194.

Casonatto, M.S., Arantes, S.A.C.M., Rieger, E.A., Andrade, E.A. 2014. How glyphosate may affect transgenic soybean in different soil and phosphorus levels. Planta Daninha 32: 843-850.
Constantin, J., Oliveira Jr., R.S.E., Gheno, E.A., Biffe, D.F., Braz, G.B.P., Weber, F., Takano, H.K. 2016. Prevention of yield losses caused by glyphosate in soybeans with biostimulant. African Journal of Agricultural Research 11:1601-1607.

Correia, N.M., Durigan, J.C., Leite, G.J. 2008. Seletividade da soja transgênica tolerante ao glyphosate e eficácia de controle de Commelina benghalensis com herbicidas aplicados isolados e em misturas. Bragantia 67: 663-671.

Farias, J.R.B., Nepomuceno, A.L., Neumaier, N. Circular Técnica 48 - Ecofisiologia da soja. 2007. http://cnpso.embrapa.br/download/cirtec/ circtec48.pdf< Acesso em: 06 Set. 2016>

Fundação Pró Sementes. Licenciamento de cultivares de soja, FPS Iguaçu RR. 2016. http:// fundacaoprosementes.com.br/cultivares/index. php?id=44<Acesso em 07 Nov. 2016>

Galon, L., Pinto, J.J.O., Agostinetto, D., Dal Magro, 2007. Controle de plantas daninhas e seletividade de herbicidas à cultura da soja, aplicados em dois volumes de calda. Revista Brasileira de Agrociência, 13: 325-330.

Gazola, T., Dias, M.F., Belapart, D., Castro, E.B., Bianchi, L. 2016. Efeitos do diclosulam na soja cultivada em solos de diferentes classes texturais. Revista Brasileira de Herbicidas 15: 353361.

Heap, I.M. Weed Science - Herbicide resistant weeds in Brazil. 2016. http://weedscience. com<Acesso em 01 Jun. 2016>

Lopes-Ovejero, R.F., Soares, D.J., Oliveira, W.S., Fonseca, L.B., Berger, G.U., Soteres, J.K., Christoffoleti, P. 2013. Residual herbicides in weed management for glyphosate-resistant soybean in Brazil. Planta Daninha 31: 947-959.

Mahoney, K.J., Tardif, F.J., Robinson, D.E., Nurse, R.E., Sikkema, P.H. 2014. Tolerance of soybean (Glycine max L.) to protoporphyrinogen oxidase inhibitors and very long chain fatty acid synthesis inhibitors applied pre-emergence. American Journal of Plant Sciences 5: 1117-1124.

Melhorança Filho, A.L., Martins, D., Pereira, M.R.R., Espinosa, W.R. 2010. Efeito de glyphosate sobre características produtivas em cultivares de soja transgênica e convencional. Biosciense Journal 26: 322-333.

Oliveira Jr., R.S. 2011. Mecanismos de ação dos herbicidas. In: Oliveira Jr., R.S., Constantin, J., Inove, M.H. Biologia e manejo de plantas daninhas. Omnipax, Curitiba, Brasil. p.348.

Oliveira Jr., R.S., Dvoranen, E.C., Constantin, J., Cavalieri, S.D., Franchini, L.H.M., Rios, F.A., Blainski, E. 2008. Influência do glyphosate sobre 
a nodulação e o crescimento de cultivares de soja resistente ao glyphosate. Planta Daninha 26: 831-843.

Osipe, J.B., Oliveira Jr., R.S., Constantin, J., Biffe, D.F., Rios, F.A., Franchini, L.H.M., Raimondi, M.A. 2014. Seletividade de aplicações combinadas de herbicidas em pré e pós-emergência para a soja tolerante ao glyphosate. Bioscience Journal 30: 623-631.

Santos, J.B., Ferreira, E.A., Reis, M.R., Silva, A.A., Fialho, C.M.T., Freita, M.A.M. 2007. Avaliação de formulações de glyphosate sobre soja Roundup Ready. Planta Daninha 25: 165-171.

SBCPD. 1995. Procedimentos para instalação, avaliação e análise de experimentos com herbicidas. SBCPD, Londrina, Brasil. p.42.

Sementes Goiás. Variedade, NA 5909 RR. 2016. http://sementesgoias.com.br/?link=variedade\& vari=na5909rg<Acesso em 07 Out. 2016>

Taylor-Lovell, S., Wax, L.M., Nelson, R. 2001. Phytotoxic response and yield of soybean (Glycine max) cultivars treated with sulfentrazone or flumioxazin. Weed Technology 15: 95-102.

Zhu, J., Patzoldt, W.L., Radwan, O., Tranel, P.J., Clough, S.J. 2009. Effects of photosystem-IIinterfering herbicides atrazine and bentazon on the soybean transcriptome. The Plant Genome 2: 191-205.

Zobiole, L.H.S., Oliveira Jr., R.S., Huber, D.M., Constantin, J., Castro, C., Oliveira, F.A., Oliveira, A. 2010. Glyphosate reduces shoot concentrations of mineral nutrients in glyphosate-resistant soybeans. Plant and Soil 328: 57-69. 